\title{
Relationship Between Professional Self-Esteem and Job Stress among Psychiatric Nurses Working at El-Abbassiya Psychiatric Hospital
}

\author{
Amal Elias Abdel-Aziz ${ }^{1}$ \& Eman El Sayed Bauomey ${ }^{2}$. \\ ${ }^{1 \& 2}$ Lecturer of Psychiatric- Mental Health Nursing-Faculty of Nursing, Ain Sham University, Egypt.
}

\begin{abstract}
Professional self-concept is the individual's perception of own self as a professional person. Stress is considered a common phenomenon in nursing due to the nature of clinical environments. However, the relationship between these two variables is unclear in the review of the literature. Accordingly, this study was aiming to assess the relationship between professional self-esteem and job stress among psychiatric nurses working at El- Abbassiya Psychiatric Hospital which is affiliated to the General Secretariat of Mental Health and Ministry of Health, Cairo, Egypt. Subjects of the study included 220 nurses of both sexes. Tools of data collection were Aricak's Professional SelfEsteem Scale and Psychiatric Nurses' Job Stress Scale (PNJSS) and Socio demographic sheet was used as the first part of the first tool (Aricak's Professional Self-Esteem Scale). The results indicated that, there was no significant relation between professional self-esteem and job stress among nurses. The researchers recommended future interventions programs to promote professional self-esteem among psychiatric nurses.
\end{abstract}

\section{Keywords: Professional Self-Esteem-Job Stress, Psychiatric Nurses}

\section{Introduction}

Professional self-concept is regarded as a person's perception of self as a professional which influences thinking, role development, behavior, and professional performance. It seems that a number of the academic disciplines and professions require a higher self-concept among which nursing is of greater importance in this regard (Cowin, Johnson, Craven \& Marsh, 2008).

Self-esteem is one of the most crucial parts of a person's work life, it refers to the perception the individual possesses of self-worth (Ghezelbash, Rahmani, Peyrovi, Inanloo\& Shekarchian, 2015). Nurses with healthy self-esteem have better performance in their work, have a more positive attitude towards their role, able to provide better quality care, satisfied with the job, fully motivated to own profession, think with morals and values to make a successful professional image and can handle stressful events more effectively, while nurses with low self-esteem are not likely to do so (Shrestha\& Ghimire, 2019).

Psychiatric nursing is regarded as one of the most stressful occupations in the world as, psychiatric nurses are always faced with specialized work demands, as well as, the risk for job stress. A variety of factors might influence a professional's response to stressful situations including; past work experiences, professional training, and individual's personality style and self-esteem (Zaki, 2016).

According to the national institute for occupational safety health of Saudi Arabia, nursing was found to be one of the jobs that had boundless than anticipated level of stress. It was also found that, stress brought harmful impacts on both nurses' health and their ability to cope with job demands (Adriaenssens, De Gucht \& Maes, 2013).

Psychiatric nurses are professionals who assist people regain a sense of coherence over what is occurring to them, be it a result of trauma or some other form of mental distress. In most psychiatric hospitals, nurses have to work in a highly stressful environment where they face stressors like shortage of nurses, unpredictable patient behavior like aggression and violence in the unit. Job stress is defined as the stress connected with professional or work environment, a pressure that overrun when the burdens of the job go beyond the capability of an individual to react efficiently (Stuhlmiller, 2003).

Even though many of the job stress confronted by psychiatric nurses are similar to those stated by staff in other nursing specialties, a number of difficulties relate explicitly to mental health settings. Psychiatric nursing is being considered as a stressful specialty, with low job satisfaction. Long term exposure to jobrelated stress can lead to burnout and reduce their level of satisfaction (Konstantinos \& Christina, 2016). Nursing is perceived as a strenuous job with high and difficult demands. The high job demands and the combination of too much responsibility and too little authority have been identified as some of the primary sources of occupational stress among nursing staff. Job related stress can result in loss of compassion for patients and increased incidences of practice errors and therefore, is unfavorably associated to quality of care 
(Sarafis, Rousaki, Sounis, Malliarou, Lahana, Bamidis, Niakas\& Papastavrou, 2016).

Nursing stress affects the performance of nurses, in addition to the individual consequences which occurs as physical, psychological and behavioral disorders. Such stress can lead to dissatisfaction or reduced job satisfaction, job fatigue, increased absenteeism and burnout, reduced productivity, increased nursing errors and ultimately reduced quality of nursing care which endangers patients' health (Hosseyni, Moeeini, Hezaveie \& Moghimbeygi, 2015).

Nurses are attempts to adapt to several situations and people and behave in the best way depend on their images of themselves. Professional self-esteem is essential to feeling able and the ability to show that in one's professional performance; poor self-esteem results in individuals' under estimating themselves and failure to use their knowledge, skills, and professional capabilities. Accordingly, it is believed that high self- esteem contributes to nurses' ability to deal with several jobs stressful situations and perform their task (Parandavar, Rahmanian \& Jahromi, 2016).

\section{Significance of the study}

Performing special tasks in carrying out the patients' care and quality of the performance require something beyond knowledge. For instance, negative self-esteem is an obstacle to independent and effective performance and those who possess a low professional self-esteem are afraid of having authority, work routinely, avoid initiative, are resistant against changes, and have a negative attitude toward themselves. On the other hand, positive professional self-esteem helps nurses to perform their responsibilities at a perfect level and desirably use their experiences, it is also assists them in controlling the effects of stressful working environments (Badiyepeyma, Hojjat, Parandavar, Ramezanli \& Mosalanejad, 2014) So, studying the relationship between professional self-esteem and job stress among psychiatric nurses can help healthcare agencies and researchers to understand how to help nurses provide high quality patients' care with the controlling and coping with the stressful working environments which can lead to burnout and at the light of the findings of this study, further researches can also proceed at the field of nursing as a profession to increase nurses' level of satisfaction.

\section{Subjects \& Methods}

Aim of the study

This study was aiming to assess the relationship between professional self-esteem and job stress among psychiatric nurses working at El-Abbassiya Psychiatric Hospital.
Research questions

This study should answer the following questions:

- What are the levels of professional self-esteem and job stress among psychiatric nurses working at El- Abbassiya Psychiatric Hospital?

- What is the relationship between nurses' professional self - esteem and job stress among psychiatric nurses working at El-Abbassiya Psychiatric Hospital?

\section{Research design}

A descriptive, correlational design was used in this study.

\section{Research Setting}

This study was conducted at El-Abbassiya Psychiatric Hospital. It is the oldest and biggest hospital for psychiatric illnesses in Cairo, affiliated to the General Secretariat of Mental Health and Ministry of Health of Egypt. The hospital consists of twenty-one old free sections; ten sections for males and eleven sections for females. There are also four forensic sections; three sections for males and one for females and two new buildings; one building for males and the other building for females.

\section{Sample size}

Based on the sample size equation, 220 nurses were participated in the study from the total number (750) of nurses who were available in all departments of ElAbbassiya Psychiatric Hospital at the year 2018.

The sample was selected according to an equation to determine the size of the study sample. Sample size was calculated using $\mathrm{n}=\mathrm{N} \times \mathrm{P} 1-\mathrm{P}\left[\left[\mathrm{N}-1 \times d^{2} \div \mathrm{Z}^{2}\right]+\right.$ $1-\mathrm{P}$ P] $\mathrm{n}=$ sample size $\mathrm{N}=$ population size $\mathrm{Z}=$ standard score corresponding to the level of significance equal to 0.95 and $1.96 \mathrm{~d}=$ the error rate is equal to $0.05 \mathrm{P}=$ ratio provides a neutral property 0.5 .

\section{Subjects of the study}

The subjects of this study included; 220 psychiatric nurses working at the previously mentioned setting in the morning shift who were available at the time of the study (from the beginning of May 2018 to the end of July 2018) and were fulfilling the following criteria:

\section{Inclusion criteria}

Age: 20 - 35 years.

Sex: Both sexes.

Qualification: Diploma of technical nursing school\& diploma of technical nursing institute.

Years of experience: Working for at least one year. Exclusion criteria

Nurses who were free from psychiatric disorders.

Tool of data collection

1. A-Socio-demographic sheet

It is the first part from the first tool for collecting data related to nurses' age, sex, qualification, marital status, resident area and years of experience. 


\section{B- Aricak's Professional Self-Esteem Scale}

It is the second part of the first tool that is originally developed by Aricak (1999) to assess professional self-esteem. This scale comprises of 37 items with 18 positive and 19 negative statements which was divided into five subscales of professional self-esteem including; acceptance of profession, 12 items, pride in the profession, 5 items, value of the profession, 11 items, belief in professional capabilities, 4 items, and belief in functionality of profession, 5 items.

\section{Scoring systems}

Each statement was graded as "strongly agree 5", "agree 4", "undecided 3", "disagree 2",and "strongly disagree 1".

Positively scored items were; $2,5,7,9,11,13,14$, $16,18,20,24,26,28,30,31,32,35$ and 36 . Whereas, negatively scored items were; $1,3,4,6,8,10,12,15$, $17,19,21,22,23,25,27,29,33,34$ and 37.

The maximum score of the nurse on the scale should be 185 , while the minimum score should be 37 .

The total score is categorized as follows:

$37<74$ indicate low professional self esteem.

$74<148$ indicate moderate professional self esteem.

148 to 185 indicate high professional self esteem.

2- Psychiatric Nurses' Job Stress Scale (PNJSS)

It was originally developed by Yada (2011) and modified by Yada (2011) to assess job-related stressors unique to psychiatric nurses. The scale consists of 22 items with 9 positive statements (psychiatric nursing ability) and 13 negative statements (attitude of patients were 6 statements\& attitude toward nursing were 7 statements) which was divided into four subscale;

\section{Scoring systems}

Each item was rated on three point Likert scale; $1=$ disagree, $2=$ to some extent and $3=$ agree.

The maximum score of job stress on the scale is "66" which categorized as follows;

- 32 to 45 are considered mild stressed.

- 46 to 59 are considered moderate stressed.

- 60 and above are considered high stressed.

\section{Pilot study}

A pilot study was conducted on 22 subjects to examine the feasibility, practicability and clarity of the language. It was also used to estimate time needed to fill the sheets which ranged between 25-35 minutes. Staff nurses who participated in the pilot study were excluded from the main study sample. Validity and reliability of the study tools were also conducted for the accuracy of the used tools.

The analysis of the pilot study data had added a lot of information to the researchers and helped them in sample size calculation but this data didn't enter in the final analysis.

\section{Ethical considerations}

After securing official requirements for carrying out this study, the subjects were informed about choosing to participate or not. The researchers took oral consents from the nurses to participate, they were informed about their right to withdraw at any time without giving a reason and they were also informed that, the data will be anonymous, and used only for the purpose of the study. The researchers explained the purpose and nature of the study to the nurses and reassured them about the confidentiality of the information given.

\section{Field work}

Once the permission granted to proceed the study, data were collected 2 days a week during the morning shift on Monday and Wednesday (from 9.00 am to $1.30 \mathrm{pm}$ ) for about 25- 35 minutes for each staff nurse, data collection lasted about three months, from the beginning of May 2018 to the end of July 2018. The researchers interviewed with each staff nurse individually (who was agreed to participate in the study). The questionnaires readied and choices recorded by each staff nurse. After collecting the answered sheets from the nurse, the researchers moved to another one to repeat the same previous steps, until completion of the process of data collection.

\section{Statistical analysis}

Data was analyzed using Statistical Package for Social Sciences (SPSS) version 20.0; analyzing and scoring sheets were followed by tabulation and calculation. Data were presented using descriptive statistics in the form of means \pm standard deviations for quantitative variables. Spearman correlation used for assessment of interrelationship among quantitative variables of professional self-esteem, and job stress dimensions. Spearman correlation also used for assessment of interrelationship among quantitative variables and scores, to assess the relationship between professional self-esteem, and job stress dimensions as dependent variable and staff nurses' age, sex, qualification, marital status, residence area and years of experience.

A multiple regression analysis conducted to investigate the relationship between professional selfesteem and job stress among staff nurses. The confidence level chosen for the study was $95 \%$. The differences considered significant if the p-value was less than 0.05 at the appropriate degrees of freedom. 


\section{Results}

Table (1): Socio-demographic characteristics of psychiatric nurses under study.

\begin{tabular}{|c|c|c|}
\hline Items & No & $\%$ \\
\hline \multicolumn{3}{|l|}{ Sex } \\
\hline Male & 117 & 53.2 \\
\hline female & 103 & 46.8 \\
\hline \multicolumn{3}{|l|}{ Age } \\
\hline $20:<25$ & 43 & 19.6 \\
\hline $25:<30$ & 81 & 36.8 \\
\hline $30:<35$ & 26 & 11.8 \\
\hline$\geq 35$ & 70 & 31.8 \\
\hline $29.36 \pm 5.61$ & & \\
\hline \multicolumn{3}{|l|}{ Marital status } \\
\hline Single & 65 & 29.6 \\
\hline Married & 146 & 66.3 \\
\hline Divorced & 6 & 2.7 \\
\hline Widowed & 3 & 1.4 \\
\hline \multicolumn{3}{|l|}{ Years of experience } \\
\hline $1:<5$ years & 62 & 28.2 \\
\hline $5:<10$ years & 60 & 27.2 \\
\hline$\geq 10$ years & 98 & 44.6 \\
\hline \multicolumn{3}{|l|}{ Mean \pm SD } \\
\hline \multicolumn{3}{|l|}{ Qualification } \\
\hline Diploma of technical nursing school. & 104 & 44.5 \\
\hline Diploma of technical nursing institute. & 116 & 52.7 \\
\hline \multicolumn{3}{|l|}{ Residence } \\
\hline Rural & 59 & 26.8 \\
\hline Urban & 161 & 73.2 \\
\hline
\end{tabular}

Table (2): Professional self-esteem among nurses working at El-Abbassiya Psychiatric Hospital.

\begin{tabular}{|c|c|c|c|c|c|c|c|c|c|c|}
\hline & \multicolumn{2}{|c|}{ SA } & \multicolumn{2}{|c|}{$\mathbf{A}$} & \multicolumn{2}{|c|}{$\mathbf{U}$} & \multicolumn{2}{|c|}{ DS } & \multicolumn{2}{|c|}{ SD } \\
\hline & No & $\%$ & No & $\%$ & No & $\%$ & No & $\%$ & No & $\%$ \\
\hline \multicolumn{11}{|l|}{ Acceptance of profession } \\
\hline $\begin{array}{l}\text { I deserve better professions than my } \\
\text { current one }\end{array}$ & 40 & 18.2 & 35 & 15.9 & 75 & 34.1 & 70 & 31.8 & 00 & 00 \\
\hline $\begin{array}{l}\text { I cannot respond proudly when my } \\
\text { profession is asked. }\end{array}$ & 41 & 18.6 & 82 & 37.2 & 60 & 27.3 & 37 & 16.8 & 00 & 00 \\
\hline I chose my profession reluctantly & 00 & 00 & 39 & 17.7 & 88 & 40 & 72 & 32.7 & 21 & 9.5 \\
\hline $\begin{array}{l}\text { Because of a preference error, currently } \\
\text { I hold a profession that I do not want }\end{array}$ & 100 & 45.6 & 90 & 40.9 & 30 & 13.6 & 00 & 00 & 00 & 00 \\
\hline $\begin{array}{l}\text { I could not yet adopt the values of my } \\
\text { profession }\end{array}$ & 00 & 00 & 15 & 6.8 & 20 & 9.1 & 25 & 11.4 & 160 & 72.7 \\
\hline I despise my profession & 00 & 00 & 00 & 00 & 60 & 27.3 & 50 & 25 & 110 & 50 \\
\hline $\begin{array}{l}\text { There are times I live conflict in myself } \\
\text { because I chose this profession }\end{array}$ & 13 & 5.7 & 119 & 54 & 52 & 23.6 & 36 & 16.4 & 00 & 00 \\
\hline $\begin{array}{l}\text { I think that my abilities are not suitable } \\
\text { for my Profession. }\end{array}$ & 31 & 14.1 & 80 & 36.4 & 46 & 20.9 & 44 & 20 & 19 & 8.6 \\
\hline I consider changing my profession & 65 & 29.5 & 00 & 00 & 114 & 51.8 & 00 & 00 & 50 & 22.7 \\
\hline $\begin{array}{l}\text { I believe that my profession cannot } \\
\text { meet my needs }\end{array}$ & 00 & 00 & 00 & 00 & 57 & 25.9 & 43 & 19.6 & 120 & 54.5 \\
\hline $\begin{array}{l}\text { I think my interests are not suitable to } \\
\text { my profession }\end{array}$ & 15 & 6.81 & 35 & 15.9 & 103 & 46.8 & 38 & 17.2 & 29 & 13.1 \\
\hline $\begin{array}{l}\text { I look as if I enjoy my profession, } \\
\text { although I do not }\end{array}$ & 95 & 43.2 & 52 & 23.6 & 25 & 11.3 & 40 & 18.2 & 8 & 3.6 \\
\hline
\end{tabular}




\begin{tabular}{|c|c|c|c|c|c|c|c|c|c|c|}
\hline & \multicolumn{2}{|c|}{$\mathbf{S A}$} & \multicolumn{2}{|c|}{$\mathbf{A}$} & \multicolumn{2}{|c|}{$\mathbf{U}$} & \multicolumn{2}{|c|}{ DS } & \multicolumn{2}{|c|}{ SD } \\
\hline & No & $\%$ & No & $\%$ & No & $\%$ & No & $\%$ & No & $\%$ \\
\hline \multicolumn{11}{|l|}{ Pride in the profession } \\
\hline My profession is very important for me & 145 & 66 & 30 & 13.6 & 12 & 5.5 & 33 & 15 & 00 & 00 \\
\hline $\begin{array}{l}\text { I think I can be productive and efficient } \\
\text { in my Profession. }\end{array}$ & 90 & 40.9 & 110 & 50 & 20 & 9.1 & 00 & 00 & 00 & 00 \\
\hline I respect my profession a lot & 70 & 31.8 & 130 & 59.1 & 20 & 9.1 & 00 & 00 & 00 & 00 \\
\hline $\begin{array}{l}\text { I think my profession is a preferred and } \\
\text { desired Profession }\end{array}$ & 00 & 00 & 15 & 6.81 & 101 & 45.9 & 61 & 27.7 & 43 & 19.5 \\
\hline I am happy with my profession & 00 & 00 & 00 & 00 & 00 & 00 & 84 & 38.1 & 136 & 61.8 \\
\hline \multicolumn{11}{|l|}{ value of the profession } \\
\hline $\begin{array}{l}\text { I can give myself emotionally to my } \\
\text { profession. }\end{array}$ & 33 & 15 & 108 & 49.1 & 37 & 16.8 & 42 & 19 & 00 & 00 \\
\hline $\begin{array}{l}\text { I can succeed important and beneficial } \\
\text { things for humanity by means of my } \\
\text { profession }\end{array}$ & 45 & 20.5 & 110 & 50 & 65 & 29.5 & 00 & 00 & 00 & 00 \\
\hline $\begin{array}{l}\text { I think that my profession has a } \\
\text { brilliant future }\end{array}$ & 10 & 4.6 & 90 & 40.9 & 00 & 00 & 20 & 9.1 & 100 & 45.5 \\
\hline $\begin{array}{l}\text { I will pursue my profession because I } \\
\text { want to }\end{array}$ & 22 & 1 & 50 & 22.7 & 76 & 34.5 & 72 & 32.7 & 00 & 00 \\
\hline $\begin{array}{l}\text { I can advocate my profession easily if } \\
\text { needed. }\end{array}$ & 30 & 13.6 & 56 & 25.5 & 88 & 40 & 13 & 5.9 & 33 & 15 \\
\hline think my profession is prestigious & 24 & 10.9 & 29 & 13.2 & 96 & 43.6 & 71 & 32.3 & 00 & 00 \\
\hline $\begin{array}{l}\text { My profession has the attributes that } \\
\text { my ideal Profession would have. }\end{array}$ & 10 & 4.6 & 90 & 40.9 & 104 & 47.3 & 16 & 7.2 & 00 & 00 \\
\hline $\begin{array}{l}\text { I can perform well my professional } \\
\text { responsibilities }\end{array}$ & 149 & 67.7 & 71 & 32.3 & 00 & 00 & 00 & 00 & 00 & 00 \\
\hline $\begin{array}{l}\text { I think my standards of life is better than } \\
\text { other professionals }\end{array}$ & 82 & 37.2 & 38 & 17.3 & 00 & 00 & 100 & 45.5 & 00 & 00 \\
\hline think I am a reasonably good nurse & 85 & 38.6 & 90 & 40.9 & 45 & 20.4 & 00 & 00 & 00 & 00 \\
\hline $\begin{array}{l}\text { In my opinion I can bring about a } \\
\text { positive change inpatients' life }\end{array}$ & 36 & 16.6 & 44 & 2 & 49 & 22.3 & 25 & 11.3 & 66 & 30 \\
\hline \multicolumn{11}{|l|}{ Belief in professional capabilities } \\
\hline $\begin{array}{l}\text { I cannot concentrate on the intellectual } \\
\text { activities that My profession requires }\end{array}$ & 17 & 7.7 & 28 & 12.7 & 119 & 54.1 & 20 & 9.1 & 36 & 16.3 \\
\hline $\begin{array}{l}\text { I think I have some professional } \\
\text { deficiencies }\end{array}$ & 30 & 13.6 & 52 & 23.7 & 18 & 8.2 & 62 & 28.1 & 58 & 26.3 \\
\hline I think people do not want to meet me & 00 & 00 & 00 & 00 & 58 & 26.4 & 72 & 32.7 & 90 & 40.9 \\
\hline People do not value me as a nurse & 00 & 00 & 90 & 40.9 & 45 & 20.4 & 85 & 38.6 & 00 & 00 \\
\hline \multicolumn{11}{|l|}{ Belief in functionality of profession } \\
\hline $\begin{array}{l}\text { I don't find my profession to be } \\
\text { suitable for my Personality }\end{array}$ & 71 & 32.3 & 39 & 17.7 & 45 & 20.4 & 65 & 29.5 & 00 & 00 \\
\hline My profession is a part of myself. & 20 & 9.1 & 33 & 15 & 49 & 22.3 & 35 & 15.9 & 83 & 37.7 \\
\hline $\begin{array}{l}\text { My profession has the attributes to } \\
\text { affect people }\end{array}$ & 120 & 54.5 & 80 & 36.4 & 20 & 9.1 & 00 & 00 & 00 & 00 \\
\hline $\begin{array}{l}\text { I wish I had a profession that I can } \\
\text { proudly tell. }\end{array}$ & 85 & 38.6 & 70 & 31.8 & 15 & 6.8 & 40 & 18.2 & 10 & 4.6 \\
\hline $\begin{array}{l}\text { When I receive a negative critique } \\
\text { about my profession, I have the } \\
\text { tendency to perceive it Worthless. }\end{array}$ & 00 & 00 & 00 & 00 & 62 & 28.2 & 49 & 22.3 & 109 & 49.5 \\
\hline
\end{tabular}

Table (3): Level of professional self-esteem among nurses working at El-Abbassiya Psychiatric Hospital.

\begin{tabular}{|l|c|c|c|c|}
\hline \multicolumn{1}{|c|}{ Level of self-esteem } & No & \% & $\mathbf{X}^{\mathbf{2}}$ & P \\
\hline Mild & 15 & 6.8 & \multirow{2}{*}{44.390} & \multirow{2}{*}{.000} \\
\cline { 1 - 3 } Moderate & 135 & 61.4 & \\
\hline
\end{tabular}


Table (4): Job stress among nurses working at El-Abbassiya Psychiatric Hospital.

\begin{tabular}{|c|c|c|c|c|c|c|}
\hline & \multicolumn{2}{|c|}{ Disagree } & \multicolumn{2}{|c|}{$\begin{array}{l}\text { To some } \\
\text { extent }\end{array}$} & \multicolumn{2}{|c|}{ agree } \\
\hline & No & $\%$ & No & $\%$ & No & $\%$ \\
\hline \multicolumn{7}{|l|}{ Psychiatric Nursing Ability } \\
\hline think that I can nurse and correspond as the case requires & 49 & 22.2 & 23 & 10.6 & 148 & 67.2 \\
\hline I think that I can explain the nursing that I am doing. & 59 & 26.8 & 123 & 55.9 & 38 & 17.2 \\
\hline I think that I have the psychiatric nursing ability. & 35 & 15.9 & 101 & 45.9 & 84 & 38.2 \\
\hline I think that my experience has been made use of on the job & 5 & 2.3 & 46 & 20.9 & 169 & 76.8 \\
\hline I feel that my role as a nurse is well-defined. & 25 & 11.3 & 129 & 58.6 & 66 & 30 \\
\hline I think that I understand the patients & 5 & 2.3 & 83 & 37.7 & 132 & 60 \\
\hline I think that I can express my opinion in front of others. & 20 & 9.1 & 110 & 50 & 90 & 40.9 \\
\hline $\begin{array}{l}\text { I think that I have knowledge about the laws, the institutions } \\
\text { and the policies necessary for nursing. }\end{array}$ & 12 & 5.5 & 78 & 35.5 & 130 & 59.1 \\
\hline $\begin{array}{l}\text { I feel that the direction my nursing is advancing in is not } \\
\text { clearly defined. }\end{array}$ & 11 & 5 & 50 & 22.7 & 159 & 72.3 \\
\hline \multicolumn{7}{|l|}{ Attitude of Nurses Toward Patients } \\
\hline I feel that patients are negative for me & 93 & 42.3 & 100 & 45.5 & 27 & 12.2 \\
\hline $\begin{array}{l}\text { I feel that there are patients who have an unpleasant attitude } \\
\text { toward me }\end{array}$ & 88 & 40 & 120 & 54.5 & 12 & 5.5 \\
\hline $\begin{array}{l}\text { I feel that there are patients who are threatening and make me } \\
\text { afraid. }\end{array}$ & 62 & 28.2 & 130 & 59.1 & 27 & 12.2 \\
\hline I feel that I might get entangled in patients' behavior. & 15 & 6.8 & 64 & 29 & 141 & 64 \\
\hline I feel that I am pressured by patients' demands & 47 & 47 & 77 & 35 & 96 & 43.6 \\
\hline I feel that patients make impossible demands on me. & 22 & 10 & 65 & 29.5 & 133 & 60.5 \\
\hline \multicolumn{7}{|l|}{ Attitude Toward Nursing } \\
\hline $\begin{array}{l}\text { I feel that there is a difference between the philosophy of the } \\
\text { institution and the reality. }\end{array}$ & 84 & 38.1 & 94 & 42.7 & 42 & 19 \\
\hline I feel that there is a gap between my ideal and actual nursing. & 108 & 49 & 96 & 43.6 & 16 & 7.2 \\
\hline $\begin{array}{l}\text { I feel that there is a difference among nurses in the way of } \\
\text { thinking about of nursing. }\end{array}$ & 7 & 3.2 & 154 & 70 & 59 & 26.8 \\
\hline I feel that I have a difference of opinion with my superior & 53 & 24 & 125 & 56.8 & 42 & 19.1 \\
\hline I feel that I can do integrated nursing. & 10 & 4.6 & 92 & 41.8 & 118 & 53.6 \\
\hline \multicolumn{7}{|l|}{ Communication } \\
\hline $\begin{array}{l}\text { I think it is difficult to communicate with the family of } \\
\text { patients. }\end{array}$ & 22 & 10 & 104 & 48.1 & 94 & 42.7 \\
\hline I think it is difficult to communicate with patients. & 106 & 48.2 & 78 & 35.5 & 36 & 16.3 \\
\hline
\end{tabular}

Table(5): Level of job stress among nurses working at El-Abbassiya Psychiatric Hospital.

\begin{tabular}{|l|c|c|c|c|}
\hline \multicolumn{1}{|c|}{ Job stress } & No & \% & $\mathbf{X}^{\mathbf{2}}$ & P \\
\hline Mild & 53 & 40.1 & & \\
\cline { 1 - 3 } Moderate & 107 & 48.6 & \multirow{2}{*}{24.744} & .01 \\
\hline
\end{tabular}

Table (6): Mean score (Mean \pm SD) of professional self-esteem and job stress among nurses working at ElAbbassiya Psychiatric Hospital.

\begin{tabular}{|l|c|c|l|}
\hline \multicolumn{1}{|c|}{ Variable } & Minimum score & Maximum score & \multicolumn{1}{c|}{ Mean \pm SD } \\
\hline Professional self- esteem & 38 & 160 & $51.9 \pm 39.4$ \\
\hline Job stress & 39 & 62 & $73.3 \pm 38.8$ \\
\hline
\end{tabular}


Table (7): Correlation between each scale of professional self-esteem and job stress among nurses working at El-Abbassiya Psychiatric Hospital.

\begin{tabular}{|l|c|c|}
\hline \multicolumn{1}{|c|}{ Professional self- esteem } & R & Pob vtress \\
\cline { 2 - 3 } & .078 & $>0.5$ \\
\hline Acceptance of profession & 0.367 & $>0.5$ \\
\hline Pride in the profession & .169 & $>0.5$ \\
\hline Value of the profession & .272 & $>0.5$ \\
\hline Belief in professional capabilities & .199 & $>0.5$ \\
\hline Belief in functionality of profession & & \\
\hline
\end{tabular}

Table (8): Correlation between professional self-esteem and job stress among nurses working at El-Abbassiya Psychiatric Hospital.

\begin{tabular}{|l|c|c|}
\hline \multirow{2}{*}{\multicolumn{1}{|c|}{ Items }} & \multicolumn{2}{c|}{ Job stress } \\
\cline { 2 - 3 } & $\mathbf{R}$ & P Value \\
\hline Professional self- esteem & .134 & $>0.5$ \\
\hline
\end{tabular}

Table (1): Shows that, 53. $2 \%$ of the studied sample were males and $36.8 \%$ of the sample were at the age group between $25<30$ years old and $66.3 \%$ of the sample were married. Regarding residence, the highest percentage $(73.2 \%)$ of the sample was living in urban areas. Concerning their qualifications, the majority of them $(52.7 \%)$ graduated from a technical nursing institute and as regard the years of experience, the majority of sample (44.6\%) had 10 years of experience and more.

Table (2): Indicates that, $72.7 \%$ and $54.5 \%$ of the psychiatric nurses strongly disagreed that, they could not yet adopt the values of their profession and they believe that, their profession cannot meet their needs as regard to" acceptance of profession" sub items. Concerning to "pride in the profession" sub items, $66 \%$ of the nurses strongly agreed that, their profession is very important for them. About the "value of profession", $67.7 \%$ of the nurses strongly agreed that, they can perform well in their professional responsibilities. Regarding to "belief in professional capabilities", $54.1 \%$ of the nurses undecided that they cannot concentrate on the intellectual activities that their profession requires. As regard to "belief in functionality of profession", $54.5 \%$ of nurses strongly agreed that, their profession has the attributes to affect people.

Table (3): As observed from table "3", 61.4\% of the psychiatric nurses have a moderate level of professional self-esteem.

Table (4): Shows that, $76.8 \%$ and $72.3 \%$ of the studied nurses agreed that, their experience has been made use of on the job and they feel that the direction their nursing is advancing, is not clearly defined concerning "psychiatric nursing ability" sub items. Regarding the "attitude of nurses toward patients", it was noticed that, $64 \%$ of the nurses feel that, they might get entangled in patients' behavior. About the "attitude toward nursing", 53.6\% of the nurses agreed that they feel that they can do integrated nursing. Concerning to "communication", $48.2 \%$ of the nurses disagreed that, they think it is difficult to communicate with patients.

Table (5): Clarifies that, $48.6 \%$ of the nurses have moderate level of job stress.

Table (6 ): Shows that, the mean score of the nurses' professional self-esteem is $51.9 \pm 39.4$ and the mean score of the nurses' job stress is $73.3 \pm 38.8$.

Table (7): explains that, there is no significant correlation between professional self-esteem subscales and job stress among the nurses.

Table (8): clarifies that, total professional selfesteem score has no significant correlation with job stress.

\section{Discussion}

Nurses are among the experts who are at high risk of working stress because of their work's nature. Although all occupations have working stress, occupations which deal with human lives, such as nursing, exposure to working stress is greater and the consequences of the same stress are worse. Therefore, studying the determinants of working stress in nursing for policy-making is one of the important research priorities in health care systems. It seems that, the level of nurses' professional self-esteem can be one of the determinants of nursing stress.

Socio-demographic characteristics of psychiatric nurses

The results of the current study reveal that, more than half of the study sample were males; this may be due to the total number of male sections more than female sections in El-Abbassiya Psychiatric Hospital. This result is disagreeing with Gorgich, Zare, Ghoreishinia, Barfroshan, Arbabisarjou and Yoosefian (2017) who evaluate job stress among 
mental health nursing staff of educational hospitals in South East Iran. The result clarified that; the highest percent of nurses were females.

Concerning the qualifications and years of experience, the results of this study show that, the majority of the study sample had graduated from the Technical Nursing Institute. Most of the sample had 10 years of experience and more, as the majority of the nurses working in El-Abbassiya Psychiatric Hospital had graduated from El-Abbassiya Technical Nursing School and recruited obligatorily in ElAbbassiya Psychiatric Hospital. This result is in line with a study carried out by Mahajan \& Kaur (2017) who assessed the effect of emotional intelligence on job performance among staff nurses, they reported that, nearly half of the subjects had experience above 10 years.

Professional self-esteem among psychiatric nurses The results denote that, two thirds of the nurses strongly disagreed that, they could not yet adopt the values of their profession, this may be due to different factors as; they have been satisfied from selection of nursing profession, internalized value of helping patient, followed the working rules and regulations, achieved independent action in patients' care additionally, they have been carried out different work responsibilities. The results also explain that, half of the psychiatric nurses strongly disagreed that, their profession cannot meet their needs, as nurses have realized that, nursing is an important and interested career. Most of the psychiatric nurses explained that, they have been gained selfdependency from working as a staff nurse. This result and explanation are in the same line with Ibrahim, Akeland \& Alzghoul (2015) who explored and compared the perceptions of undergraduate males nursing students regarding the image of the nursing profession in the two different Arabian countries of Egypt and Jordan and found that, the highest percent of the nurses agreed that, nursing profession is an independent profession as nurses can make decisions by themselves and have the chance to be selfautonomies at work.

The results of the study display that, two thirds of the nurses strongly disagreed that, they despise their profession, this may be due to many factors as; they have been choose nursing career voluntarily, gained self-awareness from working as staff nurse, understand different types of personality from interacting with patients and health care team and nowadays, nursing career has become an_interesting and respected profession in the community. This result is consistent with Ingwu, Ohaeri \& Iroka (2016) who assessed the factors within the nursing profession that motivates nurses to practice nursing. Their findings indicated that, the highest prorations of the participants agreed that nursing is a well appreciated profession in the society.

The result is also consistent with Cukljek, Jureša, Bile \& Režek (2017) who determined the attitudes of nursing students toward nursing and changes in their attitudes during their study. The results explained that, students at the beginning and during the study stated that nursing is a respected profession.

Concerning to "pride in profession" sub items, the results show that, the highest percentage of psychiatric nurses strongly agreed that, their profession is very important for them. This may be due to several factors as; they have been gained lifelong skills from working as a nurse, shared in different services in the hospital such as education and quality, they have the motivation to provide efficient care to their patients and have been realized the importance of nursing care in achieving psychiatric patients' recovery. This result consistents with Tjoflat, Melissa, Mduma, Hansen, Karlsen \& Soreide (2018) who described the experiences of Tanzanian nurses on how they perceive their role as a professional nurse and their experience with nursing care; they also indicated that, nurses were proud of their role in providing nursing care to the patients.

About the" value of the profession" sub items, the findings clarify that, one third of the psychiatric nurses strongly agreed that, they can perform well, this professional responsibilities due to different issues as; they always interact all the time with difficult patients, share in different workshops and conference and incorporate different professional values during their care. The results are also agreeing with the study of Mohamed \& Mohamed (2018) who studied the perception of staff nurses regarding professional values, they found that, the total mean score related to the staff nurses' perspective on professional values was high..

The result is at the same line with Kleebthong, Chareonsuk \& Kristiansen (2018) who studied the psychiatric nurses' experiences and perceptions of their professional role when caring for older people who displayed symptoms of depression, their results clarified that, the psychiatric nurses not only engaged in therapeutic works, but they also have to concern about the humanity of their patients, as they are unique individuals and when nurses are sincere and friendly towards patients, friendship arises which fosters successful treatments.

As regard to "belief in professional capabilities" sub items, the results explain that, more half of nurses undecided that, they cannot concentrate on the intellectual activities their profession require. This may be related to several factors as, lack of clinical judgment, dual diagnosis, unstable patients' condition, performing different role not entail to nurses' role, 
uncooperative attitude among health care team furthermore, they have a lack of professional confidence to perform independent action to patient care. This result is in the same line with the study of Lyneham \& Levett-Jones (2016) who studied the insights into registered nurses' professional values through the eyes of graduating students who explained that, a professional nursing practice is possible only when nurses are aware of their professional values and act accordingly.

Finally, the results denote that, more than half of the studied sample agreed that their profession has the attribute to affect people. This may be due to their believes of the significant role in determining patients' progress during treatment phase additionally, they always share in educational activities for promoting community mental health and they are interested to maintain social prestige to nursing career and commitment to their role. This result is in the same line with the study of Shohani \& Zamanzadeh (2017) who found nurses' attitude to professionalism at the average level.

The result of this study clarifies that, more than half of the studied sample had moderate level of professional self-esteem, as professional self-esteem is a developing process determined by many factors such as; competency of performance, relationship with others, career prestige and approval from others and self-acceptance. This result is agreeing with Manomenidis, Kafkia, Minasidou, Tasoulis, Koutra, Kospantsidou \& Dimitriadou (2017) who studied the relationship between nurses' self-esteem and the interactive (moderating) role of personal and professional factors on the burnout process. Their results revealed that, nurses displayed moderate score at the self-esteem scale. This result is incongruent with Sabanciogullari \& Dogan (2017) who entitled to determine professional self-concept among nurses working in hospitals and related factors. Their results explained that, nurses have above average level of self-esteem. The result is also contradicting with Shrestha \& Ghimire (2019) who studied stress and self-esteem among nursing students, they found that, more than half of the students had low self esteem.

\section{Job stress among psychiatric nurses}

Concerning "psychiatric nursing abilities", the results of this study reveal that, about two thirds of the nurses agreed that, they think that their experience has been made use of on the job, this may be related to different influences as; they have been work under difficult work condition, suffered from poor disciplines in hospital, uncooperative attitude from medical staff, interacting with difficult patients, discrimination in reward systems with hospital systems and are regularly responsible for non-nursing activities which cause extra burden. These results are consistent with Dehghani, Mosalanejad \& Dehghan-Nayeri (2015) in their study of the factors affecting professional ethics in nursing practice which clarified that, nurses as the largest health care group, have well known and important professional values. The use of these values in nursing practice increased the quality of patients' care, nurses' abilities and occupational satisfaction, their retention in nursing and commitment to the organization.

The results also explain that, about two thirds of the psychiatric nurses agreed that, they feel that the direction their nursing is advancing, is not clearly defined. This may be due to multiple programs planned by hospital and general health sector for mental health to enhance nursing staff performance. Additionally, there is no clear process to attain professional development. Most of the nurses explained that, there were multiple programs in the hospital but they are still working as they used before. In the study done by Ghadirian, Salsali \& Cheraghi (2017) under the title; "Nursing professionalism: An evolutionary concept analysis" they explained that, nursing as a professional activity, requires a sense of responsibility, a lot of attention and any shortcomings in the training and performances of this group is arguably the quantity and quality of health services and ultimately affect public health.

Concerning "attitude to patient", the greatest proportion of the nurses under study agreed that, they feel that they might get entangled in patients' behavior. This may be due to spending long hours in patients' care and their observations always a foundation for doctors' treatment. This result is in the same line with Dawood, Mitsu \& Monica (2018) who found that, the highest percent of nurses reported that they sometimes entangled in patients' behavior in their study of perceived psychiatric nurses' job.

Regarding "attitude of nursing", half of psychiatric nurses agreed that, they feel that, they can do integrated nursing. This may be due to different factors as; they have been adjusted to hospital policy and work condition, lack of external inspection from other health disciplines, support from peers, follow functional methods in distributing nursing care and have been assume non nursing responsibilities. This result disagrees with a study carried out by Chatzigianni, Tsounis, Markopoulos \& Sarafis (2018) which was aiming to measure perceived stress levels among nurses in a Greek public general hospital, it was concluded that, most of the nurses had lack preparation and proficiency to deal with patients which enforced stress on the nurses' work and thus, they lost the capability to do their job perfectly.

About "communication", near half of the nurses disagreed that, they think it is difficult to communicate with patients. This is due to multiple 
causes as; they have interacting with patients daily, encounter patients in emergency situation, and attend different workshops about communication skills. This result goes with Yada, Lu, Omori \& Katoh (2014) who explored the specificity and structures of jobrelated stress in psychiatric dementia nurses, their findings showed that, work overload is the major stressor not their communication with the demented patients.

The results of the present study denote that, near half of the studied sample had a moderate level of job stress, this may be due to their adjustment with working condition, the satisfactory relation with health care team members, and nurses usually use emotional coping methods in dealing with job stress. This result is also congruent to the study carried out by Hassan (2017) who studied work stress level among nurses working at the Mental Health Hospital in Port-Said City. The results show that, the majority of the respondents had a moderate level of stress perceived in the psychiatric setting. The result is also supported by a study carried out by Vernekar $\&$ Shah (2018) to determine the levels of work-related stress and identify various sources of stress among nurses. They reported that, most of the studied nurses were experiencing a moderate level of stress. This result is contradicting with Gorgich, Zare, Ghoreishinia, Barfroshan, Arbabisarjou \& Yoosefian (2017) who evaluated job stress among mental health nursing staff of educational hospitals in South East Iran. Their results explained that, high percent of nurses had a low level of stress.

Relation between professional self-esteem and job stress among psychiatric nurses

The finding of this study clarify that, there is no significant relation between professional self-esteem and job stress, this may be related to different factor as; nurses have been adjusted to hospital work culture, lack of integration with other services in the community, fixed routine work and lack of appreciation from hospital administrative affair. This result is contradicting with Mosayebi, Alaee Karahroudy, Rassouli \& Nasiri (2017) who determined the correlation between the occupational stress and professional self-concept among the pediatric nurses in teaching hospitals affiliated to Shahid Beheshti University of Medical Sciences in Tehran. Their results revealed a negative linear correlation between occupational stress and professional self-concept.

This result also disagrees with Barry, Parvan, Jabbarzadeh, Parvin \& Safa (2019) who assessed the correlation between professional self-concept and stress among nursing students in clinical environments. The result denoted that, correlation coefficient of the total score of professional self- concept with the total score of stress was equal, which is considered significant.

\section{Conclusion}

The present study concluded that;

- There is a moderate level of professional self esteem among psychiatric nurses working at ElAbbassiya Psychiatric Hospital.

- There is a moderate level of job stress among psychiatric nurses working at El- Abbassiya Psychiatric Hospital.

- There is no significant relationship between professional self-esteem and job stress among psychiatric nurses working at El-Abbassiya Psychiatric Hospital.

\section{Recommendations}

- Training workshops should be conducted for nurses to enhance their professionalism.

- Further researches are needed to assess professional self-esteem as a mediator in the relationship between professionalism and burnout.

- Further researches are needed to assess the relationship between professional self-esteem and clinical performance among psychiatric nurses.

- Designing and implementing interventions programs to promote professional self-esteem among psychiatric nurses.

- Stress management program are essential for nurses to help them coping with job related stress.

\section{Reference}

1. Adriaenssens, J., De Gucht \& Maes, S., (2013): Causes and Consequences of Occupational Stress in Emergency Nurses, A Longitudinal Study. Journal of Nursing Management. Vol.12 (3), Pp.222-240.

2. Aricak, O., (1999): Group Counseling and Professional Self- Esteem through Self Improvement. An un-published $\mathrm{PhD}$ Thesis. Marmara University, Institute of Education Sciences.

3. Badiyepeyma, Z., Hojjat, M., Parandavar, N., Ramezanli, S., \& Mosalanejad, L., (2014): The Relationship between Professional Self-Concept and Nursing Students' Decision for Job Retention. J Pharm Biomed Sci., 04(02),Pp.156-161.

4. Barry, A., Parvan, K., Jabbarzadeh, F., Parvin, S., \& Safa, B., (2019): Is Professional Self-Concept Associated with Stress among Nursing Students in Clinical Setting: A 
Descriptive Correlational Research. Crescent Journal of Medical and Biological Sciences. Vol. 6 (2), Pp. 191-195.

5. Chatzigianni, D., Tsounis, A., Markopoulos, N., \& Sarafis, P., (2018): Occupational Stress Experienced by Nurses Working in A Greek Regional Hospital: A cross-Sectional Study, Iranian Journal of Nursing Midwifery Research, Vol. 23, Pp.450-457.

6. Cowin L., Johnson M., Craven R., Marsh H., (2008): Causal modeling of self-concept, job satisfaction, and retention of nurses. Int $\mathrm{J}$ Nurs Stud.; Vol.,45(10):1449-1459. doi:10.1016/j.ijnurstu.2007.10.009

7. Čukljek, S., Jureša, V., Bile, C., \& Režek, B., (2017): Changes in Nursing Student's Atittudes towards Nursing during Undergraduate Study. ActaClin Croat, Vol. 56, (1), Pp.36-43.

8. Dawood, E., Mitsu, R., \& Monica, A., (2018): Perceived Psychiatric Nurses Job: A Cross Sectional Study. Journal of Nursing and Health Science (IOSR-JNHS) Vol. 6 (2), Pp.39.

9. Dehghani, A., Mosalanejad, L., \& DehghanNayeri, N., (2015): Factors Affecting Professional Ethics In Nursing Practice In Iran: A Qualitative Study. BMC Medical Ethics.16:61.

10. Ghadirian, F., Salsali, M., \& Cheraghi, M., (2017): Nursing Professionalism: An Evolutionary Concept Analysis. Iranian. Journal of Nursing and Midwifery Research. 19(1), Pp.1-10.

11. Ghezelbash, S., Rahmani, F., Peyrovi, H., Inanloo, M., \& Shekarchian, S., (2015): Comparison of Self-Esteem among First to Fourth Year Nursing Students from Universities of Medical Sciences in Tehran. Thritajournal. $\quad$ Vol. $4(1)$ : http://thritajournal.com/en/ articles/18218.html.

12. Gorgich, A., Zare, S., Ghoreishinia, C., Barfroshan, S., Arbabisarjou, A., \& Yoosefian, N., (2017): Job Stress and Mental Health among Nursing Staff of Educational Hospitals in South East Iran. Thritajournal. Vol.6 (1), Pp. 45421.

13. Hasan, A., (2017): Work Stress, Coping Strategies and Levels of Depression among Nurses Working in Mental Health Hospital in Port-Said City. International Archives of Nursing and Health Care Journal. Vol. (3), Pp. 5-10.

14. Hosseyni, Z., Moeeini, B., Hezaveie, M., \& Moghimbeygi, A., (2015): The Effect of
Health Education Program on Female Nurses' Stress. Journal of Health System, Vol. 1(11), Pp. 43-52.

15. Ibrahim, F., Akel, D., \& Alzghoul, H., (2015): Image of Nursing Profession as Perceived by Egyptian and Jordanian Undergraduate Male Nursing Students: Comparative Study. Journal of Education and Practice.Vol.6 (14), Pp. 26-32.

16. Ingwu, J., Ohaeri, B., \& Iroka, O., (2016): The professional Image of Nursing as Perceived by Nurses Working in Tertiary Hospitals Enugu, Southeast Nigeria . African Journal of Nursing and Midwifery.4 (1), Pp.595-602.

17. Kleebthong, D., Chareonsuk, A., \& Kristiansen, L., (2018):Thai Psychiatric Nurses' Experiences and Perceptions of the Professional Role When Caring for Older People Displaying Depressive Symptoms. Open Journal of Nursing. Vol. 8(3), Pp.45-59

18. Konstantinos, N., \& Christina, O., (2016): Factors Influencing Stress and Job Satisfaction of Nurses Working in Psychiatric Units: A Research Review .Health Science Journal.Vol.10 (1), Pp. 33-37.

19. Lyneham, J., \& Levett-Jones, T., (2016): Insights Into Registered Nurses' Professional Values Through The Eyes Of Graduating Students Nurse Education in Practice. Vol. 17, Pp. 86-90.

20. Mahajan, K., \&Kaur, B., (2017): A Correlational Study to Assess The Effect of Emotional Intelligence on Job Performance among Staff Nurses Working in Selected Hospitals of Jalandhar, Punjab. International Journal of Development Research. Vol. 7, Pp.15044-15047.

21. Manomenidis, G., Kafkia, T., Minasidou, E., Tasoulis, C., Koutra, S., Kospantsidou, A., \& Dimitriadou, A., (2017): Is SelfEsteem Actually the Protective Factor of Nursing Burnout? International Journal of Caring Sciences. Vol. 10(3), 1348.

22. Mohamed, F., \& Mohamed, H., (2018): Perception of Staff Nurses Regarding Professional Values at Ain Shams Specialized Hospital. Journal of Nursing and Health Science.Vol.7 (2), Pp.60-67.

23. Mosayebi, M., AlaeeKarahroudy, F., Rassouli, M., \& Nasiri, M., (2017): Correlation of Occupational Stress with Professional Self-Concept in Pediatric Nurses. Journal of Health Promotion Management. Vol. 6(6), Pp.23-29. 
24. Parandavar, N., Rahmanian, A., \& Jahromi, B., (2016): A Study of The Relationship Between Nurses' Professional Self-Concept and Professional Ethics in Hospitals Affiliated to Jahrom University of Medical Sciences, Iran. Global Journal of Health Science; Vol. 8 (4),Pp.82-88.

25. Sabanciogullari, S., \& Dogan, S., (2017): Professional Self-Concept in Nurses and Related Factors: A Sample from Turkey. International Journal of Caring Sciences. Vol. 10 (3), Pp.1676-1684.

26. Sarafis, B., Rousaki, E., Sounis, T., Malliarou, M., Lahana, L., Bamidis, P., Niakas, D., \& Papastavrou, E., (2016):The Impact of Occupational Stress on Nurses' Caring Behaviors and Their Health Related Quality of Life. BMC Nursing. DOI: 10.1186/s12912-016-0178-y.

27. Shohani, M., \& Zamanzadeh, V., (2017): Nurses' Attitude Towards Professionalization and Factors Influencing It. Journal of Caring Sciences. Vol. 6(4), Pp.345-357.

28. Shrestha, S., \& Ghimire, S., (2019): Stress and Self-Esteem among Nursing Students at Private Medical College, Chitwan. Journal of Chitwan Medical College.Vol.9 (27), Pp. 4146.

29. Stuhlmiller, C., (2003): Trauma, Culture and Meaning: Central Issues for Mental Health Nursing. International Journal of Mental Health Nursing. Vol. 12 (1), Pp.1-3.

30. Tjoflat, I., Melissa, J., Mduma, E., Hansen, B., Karlsen, B., \&Soreide, L., (2018): How do Tanzanian Hospital Nurses Perceive Their Professional Role? A Qualitative Study: WIELEY Nursing Open.

31. Vernekar, S., \& Shah, H., (2018): A Study of Work-Related Stress among Nurses in a Tertiary Care Hospital in Goa, International Journal of Community Medicine and Public Health. Pp.657-661.

32. Yada, H., Lu, X., Omori, H., \&Katoh, T., (2014): Job-Related Stress in Psychiatric Nurses in Japan Caring for Elderly Patients with Dementia. Environ. Health Prev. Med., Vol. 9, Pp.436-443.

33. Yada, H., (2011): Development of The Psychiatric Nurse Job Stressor Scale (PNJSS), Journal of Health Sciences, Vol. 65 (6), Pp.567-575.

34. Zaki, A., (2016): Job Stress and Self- Efficacy among Psychiatric Nursing Working in Mental Health Hospitals at Cairo. Journal of Education and Practice.Vol. 7 (20), Pp.103 113. 